\title{
KONSEP ARSITEKTUR EKOLOGI PADA RUMAH PEMASYARAKATAN BERBASIS KOMUNITAS DAN PENGEMBANGAN DIRI
}

\author{
Octavianus Bryan ${ }^{1)}$, Maria Veronica Gandha²) \\ 1)Program Studi S1 Arsitektur, Fakultas Teknik, Universitas Tarumanagara, kohocta123@gmail.com \\ 2) Program Studi S1 Arsitektur, Fakultas Teknik, Universitas Tarumanagara, mariag@ft.untar.ac.id
}

\begin{abstract}
Abstrak
Tingkat kriminalitas yang terus mengalami peningkatan dari tahun ke tahun di berbagai wilayah di Indonesia mengindikasikan salah satunya bahwa sistem pemasyarakatan belum berjalan efektif terutama dalam mengurangi kasus residivisme. Pembentukan stigma sosial dan pandangan negatif dari masyarakat terhadap status narapidana juga mempunyai peran yang besar sehingga mantan warga binaan tidak selalu diperlakukan sebagaimana mestinya dalam lingkungan masyarakat, terutama dalam kehidupan ekonomi dan sosial. Konsep desain dalam proyek ini bertujuan menciptakan Lembaga Pemasyarakatan yang mendukung integrasi warga binaan secara utuh ke dalam masyarakat, yang diharapkan dalam prosesnya dapat menjadi solusi untuk mengatasi kelebihan kapasitas pada sebagian besar Lembaga Pemasyarakatan di Indonesia. Proyek ini fokus menciptakan inovasi untuk Lembaga Pemasyarakatan di Indonesia, dengan tetap memperhatikan standar dan peraturan yang ditentukan dalam Undang-Undang. Metode perancangan diimplementasikan dengan pendekatan ekologi serta konsep alam dan fleksibilitas dalam komunitas. Interaksi yang terjalin dalam komunitas itu yang bertujuan untuk merehabilitasi para warga binaan baik secara personal maupun sosial. Proyek ini menghasilkan desain ekologi yang bersifat bebas dengan ruang-ruang komunitas yang bisa dimanfaatkan untuk menjalin interaksi dalam ekologi itu sendiri, baik antara warga binaan dengan warga binaan, dengan masyarakat umum, maupun dengan lingkungan alam dan segala elemen pendukungnya. Konsep fleksibilitas yang ditonjolkan pada proyek ini, tetap dalam koridor yang dijaga melalui pengawasan ketat dari para petugas melalui teknologi yang mendukung pengawasan jarak jauh bagi narapidana.
\end{abstract}

Kata kunci : Ekologi; Komunitas; Lembaga Pemasyarakatan; Warga Binaan

\begin{abstract}
The crime rate which continues to increase from year to year in various regions in Indonesia indicates one of them is that the prison system has not been effective, especially in reducing cases of recidivism. The formation of social stigma and negative views from the community towards the status of prisoners also has a big role so that former assisted residents are not always treated properly in the community, especially in economic and social life. The design concept in this project aims to create a Penitentiary that supports the complete integration of inmates into the community, which is expected to be a solution in the process to overcome the overcapacity in most of the correctional institutions in Indonesia. This project focuses on innovations for correctional institutions in general in Indonesia, while taking into account the standards and regulations stipulated in law. The design method is implemented with an ecological approach and the concept of nature and flexibility in the community. The interactions that exist in the community are aimed at rehabilitating the assisted members,
\end{abstract}


both personally and socially. This project produces an ecological design that is free with community spaces that can be used to establish interactions within the ecology itself, both between the assisted residents and the assisted residents, with the general public, as well as with the natural environment and all its supporting elements. The concept of flexibility that is highlighted in this project, remains in a corridor that is guarded through the close supervision of officers through technology that supports remote surveillance of prisoners.

Keywords: Assisted People; Community; Ecology; Penitentiary

\section{PENDAHULUAN}

\section{Latar Belakang}

Arsitektur selalu mengalami perkembangan dari masa ke masa, berbagai inovasi menjadi elemen penting untuk menyesuaikan fungsi arsitektur terhadap lingkungan di sekitarnya. Berbagai hal baru dalam bidang teknologi juga seiring dengan perkembangan arsitektur itu sendiri sehingga diharapkan secara fungsional mampu menciptakan interaksi baru yang lebih konstruktif antara manusia, lingkungan, dan makhluk hidup lain di sekitarnya. Indonesia sendiri memiliki keanekaragaman dalam bidang arsitektur, mulai dari arsitektur tradisional, arsitektur vernakular, arsitektur kontemporer, dan berbagai jenis lain. Berbagai jenis arsitektur tersebut dibangun salah satunya untuk mengatasi berbagai masalah yang ada di lingkungan. Prospek dan orientasi arsitektur diharapkan mampu mengarah pada penyelesaian masalah di masa depan, bukan hanya di masa sekarang. Oleh sebab itu berbagai konsep diusung guna menciptakan arsitektur yang melampaui ekologi, yang mampu menciptakan inovasi untuk menyelesaikan berbagai masalah yang ada.

Salah satu masalah penting yang terjadi di Indonesia adalah terkait dengan sistem pemasyarakatan yang dijalankan yang tentu berkaitan dengan kejahatan. Kejahatan atau kriminalitas sendiri adalah gejala sosial yang senantiasa dihadapi oleh masyarakat Indonesia. Kejahatan tidak bisa sepenuhnya lepas dari kehidupan masyarakat. Semua lapisan merasakan dampak kejahatan yang dilakukan oleh oknum-oknum tertentu. Tindak kejahatan sendiri menurut ahli kriminologi adalah suatu perbuatan sengaja atau perilaku seseorang dalam melanggar hukum pidana, dilakukan bukan untuk pembelaan diri atau pembenaran, dan ditetapkan oleh negara sebagai kejahatan serius atau kejahatan ringan (Hagan,2013). Sistem pemasyarakatan yang berjalan saat ini masih menimbulkan tanda tanya terkait bagaimana peran narapidana atau mantan narapidana yang telah kembali di dalam masyarakat, serta apa kontribusi yang dapat mereka berikan sehingga tidak lagi mengulangi kejahatan yang sama dan masuk ke dalam penjara. Kasus residivisme di Indonesia menjadi salah satu dampak besar yang terjadi akibat belum efektifnya sistem pemasarakatan di dalam Lembaga Pemasyarakatan. Sebuah penelitian yang dilakukan oleh Prambudi (2016) menemukan bahwa narapidana residivis melakukan residivisme karena beberapa faktor yang bersumber dari internal atau diri narapidana itu sendiri. Faktor-faktor internal tersebut antara lain faktor keluarga yang kurang terbuka, faktor ekonomi yang kurang mapan, faktor emosional, faktor pemutusan hubungan kerja dari tempat kerja dan akhirnya ikut serta dalam tindakan kejahatan. Strategi untuk mengatasi hal tersebut dapat diterjemahkan dalam konsep baru penjara atau Lembaga Pemasyarakatan itu sendiri. Interaksi yang terjadi di masyarakat saat ini dengan persepsi negatif dan stigma sosial yang melekat pada status narapidana harus dapat dihilangkan salah satunya dengan membangun konsep baru beyond ecology, sehingga prospek pengembangan kualitas narapidana ke depannya dapat secara konstruktif membangun ekologi yang lebih positif antara narapidana dengan masyarakat.

Berdasarkan indeks kejahatan tahun 2020 yang dirilis oleh situs Numbeo, hasil survey menunjukkan bahwa Indonesia berada di posisi 76 dari total 133 negara dengan angka indeks kejahatan mencapai 53,94 . Masalah utama dari fenomena ini justru terjadi di lingkungan pembinaan masyarakat, di mana kelebihan kapasitas (over crowded) menjadi masalah rumit yang berpengaruh terhadap timbulnya 
kasus-kasus kejahatan lain, seperti penyalahgunaan narkoba, pembentukan jaringan kriminal, perkelahian, perampasan hak, dan lain sebagainya. Di Indonesia sendiri, hampir seluruh Lembaga Permasyarakatan dan Rumah Tahanan mengalami kelebihan kapasitas yang merata. Menurut data Direktorat Jenderal Permasyarakatan Departemen Hukum dan HAM, jumlah narapidana di Lembaga Penasyarakatan dan Rumah Tahanan seluruh Indonesia mengalami peningkatan dari tahun 2005-2008, di mana pada tahun 2005 jumlah narapidana mencapai 97.671 orang, pada tahun 2006 bertambah 15.073 orang menjadi 112.744 orang, pada tahun 2007 bertambah 14.494 orang menjadi 127.238 orang, sedangkan pada tahun 2008 bertambah sebanyak 2.837 orang, sehingga jumlahnya menjadi 130.075 orang. Dari data tersebut, penurunan jumlah penambahan narapidana terjadi secara signifikan pada tahun 2008. Hal itu dikarenakan kebijakan Ditjen Pemasyarakatan pada tahun 2007 yang tertuang dalam Peraturan Menteri Hukum dan Hak Asasi Manusia tentang syarat dan tata cara pelaksanaan asimilasi, pembebasan bersyarat, dan cuti menjelang bebas, dan cuti bersyarat. Hal ini menunjukkan bahwa peran pemerintah sangat besar bagi terciptanya Lembaga Permasyarakatan yang ideal untuk pembinaan masyarakat di dalamnya.

Di Indonesia standar ideal dalam lapas dan rutan adalah satu orang sipir yang bertugas menjaga 20 orang warga binaan, sementara di Indonesia sendiri perbandingan rata-rata nasional tahun 2017 justru 1 sipir berbanding dengan 56 orang warga binaan, bahkan perbandingan sipir dan warga binaan di lapas bagan siapi api menjapai 1:160 yang juga menjadi lapas terpadat di Indonesia. Program pembinaan dan keterampilan bagi para warga binaan justru menjadi hilang karena minimnya tempat untuk melaksanakan kegiatan tersebut. Alhasil, warga binaan hanya memanfaatkan fasilitas seadanya seperti untuk olahraga dan ibadah untuk membunuh waktu selama berada di dalam lapas. Hal tersebut sungguh menjadi ironi di mana lapas yang seharusnya menjadi tempat rehabilitasi dan pengembangan diri, namun malah menjadi sarang penyakit yang tidak mampu memberikan perubahan positif. Selain itu, kepadatan pada setiap kamar di mana idealnya dihuni oleh 13 orang warga binaan di ruang seluas 24 meter persegi, tetap di lapas bagansiapiapi dihuni hingga 54 orang warga binaan. Hal ini tentu berimplikasi pada kenyamanan warga binaan dan kesehatan udara di dalamnya.

Lembaga permasyarakatan yang seharusnya berorientasi pada re-integrasi sosial yang menekankan kepada upaya penyatuan kembali hubungan hidup, kehidupan dan penghidupan seorang narapidana ke tengah-tengah masyarakat, namun seakan berubah haluan menjadi sekolah kejahatan. Minimnya pembinaan di penjara, menyuburkan dendam sosial. Dalam kondisi sosial yang tidak berubah, selepas dari penjara tak sedikit yang kembali melakukan pelanggaran pidana dengan skala yang lebih besar. Pandangan negatif dari masyarakat terhadap status narapidana atau mantan narapidana membentuk suatu batas imajiner yang begitu kentara dan dirasakan oleh para mantan warga binaan tersebut. Direktur Jenderal Pemasyarakatan I Wayan Dusak dalam wawancara dengan program Satu Indonesia Net TV memberikan contoh bagaimana seorang pelaku teroris yang telah menjalankan hukumannya dipenjara dan kembali ke masyarakat, namun tidak ada yang mau menerimanya kembali, termasuk keluarga dan orang-orang terdekatnya. Alhasil orang itu kembali melakukan kejahatan lagi dan kembali dijebloskan ke penjara. Latar Belakang Narapidana (napi) dan mantan napi, selama ini masih selalu dikaitkan dengan penjahat yang berbahaya dan pelanggaran pidana. Kebanyakan orang tidak peduli dengan proses hukum yang sering tidak adil, walaupun menyadari kondisi orang-orang yang tidak bersalah namun karena hukum yang bersifat karet, mereka akhirnya menjadi tersangka dan dimasukkan ke penjara. Di sisi lain, napi sebetulnya hanyalah pelaku pelanggaran yang tertangkap (yang kemudian menjadi napi). Sedangkan pelaku pelanggaran yang tidak tertangkap, tidak menjadi napi. Hasil penelitian membuktikan (Psychology in Prisons, 1990), setiap orang pernah melakukan pelanggaran pidana - namun hanya sebagian kecil saja yang tertangkap. Maka secara kualitatif, napi (dan eks napi) sama dengan masyarakat biasa, sebetulnya sama saja: pernah melakukan pelanggaran pidana. 


\section{Rumusan Permasalahan}

Kelebihan kapasitas yang terjadi pada sebagian besar Lembaga Pemasyarakatan di Indonesia mempunyai dampak besar bagi timbulnya kasus-kasus kejahatan lain, seperti penyelundupan obat terlarang di dalam Lembaga Pemasyarakatan karena kurangnya pengawasan dari tenaga sipir, kasus residivisme yang meningkat akibat tidak efektifnya rehabilitasi bagi narapidana di dalam Lembaga Pemasyarakatan, konflik interpersonal antara narapidana dengan petugas Lembaga Pemasyarakatan, hingga timbulnya beragam jenis penyakit akibat lingkungan di dalam LAPAS yang terlalu padat dan tidak memadai sehingga mudah menularkan penyakit dari satu orang ke orang lain. Hal-hal negatif tersebut berpengaruh pada terus berkembangnya stigma sosial dan persepsi negatif masyarakat terhadap status narapidana sehingga banyak dari mereka yang akhirnya tidak mendapatkan tempat dalam pekerjaan, kehidupan ekonomi, dan sosial, serta dalam beberapa kasus ditinggalkan oleh keluarga atau kerabatnya setelah keluar dari Lembaga Pemasyarakatan (Akhyar dkk., 2014), ditambah pula tidak efektifnya proses rehabilitasi di dalam LAPAS yang berujung salah satunya pada terjadinya kembali kasus residivisme sebagai suatu lingkaran masalah yang seakan tidak pernah putus dan belum secara efektif dapat ditangani maksimal oleh sistem pemasyarakatan di Indonesia.

\section{Tujuan}

Studi ini bertujuan untuk memberikan usulan atas rumusan permasalahan melalui rancangan proyek yang mampu memperbaiki secara konstruktif konsep Lembaga Pemasyarakatan di Indonesia agar dapat lebih efektif dan efisien dalam proses rehabilitasi serta pengembangan diri bagi narapidana. Tujuan lainnya antara lain : memberikan ruang yang lebih luas bagi narapidana untuk mengekspresikan diri dan bakatnya; meningkatkan kemampuan dalam bidang teknologi yang seiring dengan perkembangan zaman untuk narapidana; memberikan wadah untuk menimba pendidikan baik dalam bidang formal maupun nonformal; mengurangi persentase kasus residivisme yang tidak menunjukkan tanda penurunan; menghilangkan stigma sosial dan persepsi negatif masyarakat terhadap narapidana sehingga narapidana bisa mendapatkan tempat dalam masyarakat berdasarkan nilai dan/atau kualitas dirinya, bukan penolakan karena masa lalunya. Berbagai visi dan misi yang ditujukan dalam proyek tidak sepenuhnya mengubah atau menghilangkan tatanan dan peraturan Lembaga Pemasyarakatan yang sudah ada di Indonesia, melainkan dikembangkan agar lebih efektif dan efisien dalam menciptakan sumber daya manusia yang berkualitas, mempunyai daya saing, dan mampu berpartisipasi positif dalam masyarakat setelah keluar dari Lembaga Pemasyarakatan.

\section{KAJIAN LITERATUR}

\section{Melampaui Ekologi}

Menurut Kamus Besar Bahasa Indonesia, melampaui berasal dari kata dasar lampau yang berarti lalu; lewat; masa yang lampau; masa jayanya telah lampau, sementara kata melampaui sendiri memiliki arti lewat batas; berlebih-lebih.

Kata ekologi berasal dari Bahasa Yunani oikos (rumah atau tempat hidup) dan logos (ilmu). Secara harafiah ekologi merupakan ilmu yang mempelajari organisme dalam tempat hidupnya atau dengan kata lain mempelajari hubungan timbal-balik antara organisme dengan lingkungannya. Ekologi bersifat eksploratif dengan tidak melakukan percobaan, jadi hanya mempelajari apa yang ada dan apa yang terjadi di alam. Pembahasan ekologi tidak lepas dari pembahasan ekosistem dengan berbagai komponen penyusunnya yaitu faktor abiotik dan biotik. Faktor abiotik antara lain suhu, air, kelembaban, cahaya, dan topografi, sedangkan faktor biotik adalah makhluk hidup yang terdiri dari manusia, hewan, tumbuhan, dan mikroba. Ekologi juga berhubungan erat dengan tingkatan-tingkatan organisasi makhluk hidup yaitu populasi, komunitas, dan ekosistem yang saling memengaruhi dan merupakan suatu sistem yang menunjukkan kesatuan.

Secara sederhana ilmu ekologi diartikan sebagai ilmu yang mempelajari ekosistem. Secara rinci, ekologi juga bisa diartikan sebagai sebuah studi terhadap hubungan timbal balik antara organisme dengan organisme lainnya serta benda-benda mati yang ada di sekitarnya. 
Istilah ekologi pertama kali dikemukakan oleh Ernst Haeckel (1834 - 1914). Dalam ekologi, makhluk hidup dipelajari sebagai kesatuan atau sistem dengan lingkungannya. Menurut Ernst Haeckel ekologi adalah ilmu yang komprehensif yang memperlajari hubungan antar organisme dengan lingkungannya. Burdon-Sanderson menyatakan ekologi adalah ilmu yang memperlajari hubungan/relasi eksternal antara tanaman dan hewan satu sama lain, serta keberadaannya pda masa lampau dan masa kini. Relasi eksternal tersebut untuk membedakan dengan fisiologi (relasi internal) dan morfologi (struktur). Krebs memperjelas definisi ekologi yaitu pengetahuan ilmiah mengenai interaksi yang menentukan distribusi dan kelimpahan suatu organisme (ekologi adalah mengenai dimana organisme ditemukan, berapa jumlahnya, dan mengapa). Sedangkan Ricklefs mendefinisikan ekologi sebagai ilmu lingkungan alam, terutama mempelajari hubungan mendalam antara organisme dengan lingkungan sekitarnya. Berdasarkan definisi-definisi di atas makan dapat disimpulkan bahwah ekologi adalah ilmu yang mempelajari hubungan timbal balik antar organisme atau organisme dengan lingkungannya.

Berdasarkan perkembangannya ekologi bisa disebut sebagai ilmu dasar lingkungan, ilmu yang mempelajari makhluk hidup dalam rumah tangganya atau ilmu yang mempelajari seluruh pola hubungan timbal balik antara makhluk hidup sesamanya dengan komponen di sekitarnya. Ekologi menganut prinsip keseimbangan dan keharmonisan semua komponen alam. Terjadinya bencana alam merupakan contoh keseimbangan dan keharmonisan alam terganggu. Ekologi memandang makhluk hidup sesuai dengan perannya masing-masing. Semua makhluk hidup di alam memiliki peran yang berbeda dalam menciptakan keharmonisan dan keseimbangan alam.

Melampaui ekologi dapat diartikan secara harafiah sebagai proses untuk menciptakan dan mengembangkan suatu hubungan timbal balik antara makhluk hidup dengan elemen pendukung di lingkungan yang melampaui atau melewati batas hubungan timbal balik dalam ekologi yang ada pada saat ini.

\section{Lembaga Pemasyarakatan}

Lembaga Permasyarakatan atau selanjutnya disebut LAPAS merupakan tempat untuk melaksanakan pembinaan Narapidana dan Anak Didik Pemasyarakatan diatur dalam Pasal 1 angka 3 Undang-undang Nomor 12 Tahun 1995 tentang Pemasyarakatan. Sedangkan dalam Pasal 1 angka 1 Undang-undang Nomor 12 Tahun 1995 tentang Pemasyarakatan, yang dimaksud dengan pemasyarakatan adalah kegiatan untuk melakukan pembinaan warga binaan pemasyarakatan berdasarkan sistem, kelembagaan dan cara pembinaan yang merupakan bagian akhir dari sistem pemidanaan dalam tata peradilan pidana.

Menurut Keputusan Menteri Hukum dan HAM No. M.02-PK.04.10 Tahun 1990, yang disebut Lembaga Pemasyarakatan adalah unit pelaksana teknis pemasyarakatan yang menampung, merawat dan membina narapidana. Berdasarkan beberapa pengertian yang sebutkan pada undang-undang, Lembaga Pemasyarakatan tidak hanya merupakan tempat untuk membina, membimbing dan mendidik narapidana, melainkan bertujuan agar setelah mereka menyelesaikan masa pidananya, mereka memiliki kemampuan dan keterampilan dalam menyesuaikan diri sehingga mampu diterima oleh masyarakat luar. Penghuni dari Lembaga Pemasyarakatan adalah orang yang kemudiaan dinyatakan melakukan tindakan melanggar hukum dan telah diputuskan bersalah melalui proses pengadilan.

Lembaga Pemasyarakatan di Indonesia sendiri diklasifikasikan menjadi beberapa jenis. Berdasarkan Keputusan Menteri Kehakiman RI, M.01. PL.01.01, tahun 1985, tentang Pola Bangunan Lembaga Pemasyarakatan, Rumah Tahanan Negara dan Rumah Penyimpanan Barang Sitaan Negara (Departemen Kehakiman RI, Jakarta 1985). Lembaga Pemasyarakatan diklasifikasikan sebagai berikut : 


\section{Lembaga Pemasyarakatan Kelas I}

Lembaga Pemasyarakatan yang berlokasi di ibu kota provinsi daerah tingkat satu dengan kapasitas lebih dari 500 orang narapidana, dengan luas lahan minimal kurang lebih $60.000 \mathrm{~m} 2$, memiliki bengkel keterampilan kerja yang lengkap dan memadai, dimana narapidananta dikelompokan dalam jenis kelamin, tingkat kejahatan dan usia.

\section{Lembaga Pemasyarakatan Kelas II}

Lembaga Pemasyarakatan Kelas II dibedakan menjadi 2, yaitu :

- Lembaga Pemasyarakatan Kelas IIA yang berkedudukan di ibu kota DATI II dengan daya tampung 250-500 orang narapidana dengan luas lahan minimal kurang lebih $40.000 \mathrm{~m} 2$.

- Lembaga Pemasyarakatan kelas IIB, untuk wilayah kabupaten dengan daya tampung 250500 orang dengan luas lahan minimal kurang lebih $30.000 \mathrm{~m} 2$

\section{Lembaga Pemasyarakatan Kelas III}

Lembaga Pemasyarakatan dengan daya tampung maksimum 250 orang narapidana

\section{Residivisme}

Residivisme dalam pemahaman umum dipahami sebagai suatu istilah luas yang mengacu pada perilaku kriminal kambuhan (relapse of criminal behavior), termasuk karena suatu penangkapan kembali (rearrest), penjatuhan pidana kembali (reconviction), dan pemenjaraan kembali (reimprisonment). Residivis dapat diartikan sebagai orang yang melakukan pengulangan tindak pidana, sedangkan residivisme (recidivism) dimaknai sebagai kecenderungan individu atau kelompok untuk mengulangi perbuatan tercela walaupun ia sudah pernah dihukum karena melakukan perbuatan itu. Namun sebagai suatu konsep dalam hukum pidana, seseorang baru dapat disebut residivis atau melakukan perbuatan residivisme apabila orang tersebut melakukan pengulangan tindak pidana dengan syaratsyarat tertentu yang kemudian dapat berimplikasi pada pemberatan hukuman baginya (Hairi, 2018: 199-216).

Residivis berasal dari bahasa Prancis yang di ambil dua kata latin, yaitu re dan co, re berarti lagi dan cado berarti jatuh. Maka recidivis berarti suatu tendensi berulang kali hukum karena telah berulang kali melakukan kejahatan, dan mengenai resividis adalah berbicara tentang hukum yang berulang kali sebagai akibat perbuatan yang sama atau serupa.9 Aruan Sakidjo dan Bambang Poernomo menjelaskan pengertian recidive sebagai kelakuan seseorang yang mengulangi perbuatan pidana sesudah dijatuhi pidana dengan keputusan hakim yang mempunyai kekuatan hukum tetap karena perbuatan pidana yang telah dilakukannya lebih dahulu. Seseorang yang sering melakukan perbuatan pidana, dan karena dengan perbuatan-perbuatannya itu telah dijatuhi pidana bahkan lebih sering dijatuhi pidana, disebut recidivist. Kalau recidive menunjukkan pada kelakuan mengulangi perbuatan pidana, maka recidivist menunjuk kepada orang yang melakukan pengulangan perbuatan pidana.

\section{Ruang dan Waktu}

Sistem pemasyarakatan di dunia terus mengalami perkembangan dari masa ke masa, juga pemikiranpemikiran tentang inovasi sistem pemasyarakatan di masa depan yang dirangkum sebagai berikut:

\section{Masa Lalu}

Pidana penjara kuno di Bridewell sudah dilakukan melalui hukuman kurungan di dalam sel. Selain itu, pada masa ini metode pengurungan dan penhukuman yang dilakukanpun masih bervariasi. Seluruh pelaku kejahatan dihukum atas kesadaran mereka terhadap kejahatan yang telah diperbuatnya, sehingga pengawasanpun tidak terlalu ketat. Pelaku kejahatan menjadi kaum terpinggirkan yang hidup 
terpisah dari masyarakat. Sistem penghukuman di penjara terus mengalami perkembangan hingga tiba pada masa hukuman diberlakukan atas tubuh manusia. Seringkali terjadi pembakaran budak dan orang-orang kristen yang tertangkap tangan melakukan suatu kejahatan, terciptanya olahraga darah atas nama kompetisi antar manusia seperti jousting, serta penyiksaan dan eksekusi mati di depan umum. Hal ini dilakukan sebagai metode untuk membalas kejahatan asli yang dilakukan pelaku kejahatan serta mencegah terjadinya kesalahan lebih lanjut oleh individu lain. Para pelaku kejahatan yang dihukumpun merelakan dirinya untuk disiksa dan dieksekusi, karena mereka menganggap bahwa semua itu adalah bentuk pengorbanan supaya para pelaku kejahatan tersebut memperoleh pengampunan di kehidupan lain setelah bumi. Setelah meninggal dunia, tubuh mereka akan digantung di tempat yang mudah terlihat oleh masyarakat dengan tujuan sebagai pengingat hukuman bagi para pelanggar hukum.

\section{Masa Sekarang}

Over crowded menjadi salah satu faktor utama yang berkontribusi terhadap kondisi penjara yang buruk di seluruh dunia. Hal ini juga bisa dikatakan sebagai masalah tunggal terbesar yang dihadapi sistem penjara dan konsekuensinya yang paling buruk dapat mengancam jiwa, karena penjara tidak dapat lagi berfungsi efektif sebagaimana mestinya. Kepadatan bukanlah sepenuhnya karena peningkatan tingkat kejahatan, melainkan kebijakan peradilan pidana juga mengambil peran terhadap masalah ini. Kepadatan tersebut tentu dapat merusak kemampuan sistem penjara untuk memenuhi kebutuhan dasar manusia, seperti perawatan kesehatan, makanan, dan akomodasi. Hal ini juga membahayakan penyediaan dan efektivitas program rehabilitasi, pendidikan dan pelatihan kejuruan, serta kegiatan rekreasi. Penggunaan penahanan prasidang yang berlebihan serta penggunaan penjara untuk pelanggaran ringan dan kecil merupakan pendorong penting tingginya populasi penjara di hampir seluruh dunia.

\section{Masa Depan}

Prediksi dan harapan sistem pemasyarakatan di masa depan sudah terkoneksi erat dengan perkembangan teknologi. Pemanfaatan teknologi sebagai bagian penting dari sistem pemasyarakatan, seperti sistem pemasyarakatan virtual, penjara jarak jauh yang terhubung dengan sistem komputer (Allen dkk., 2020), pembekuan narapidana dalam jangka waktu tertentu dalam sebuah kapsul/tabung, hukuman penjara dengan menggunakan VR, atau bahkan mungkin sudah tidak ada lagi penjara karena pola hidup masyarakat yang terbentuk sudah mandiri, dinamis, terstruktur, dan sadar akan prioritasnya.

\section{Komunitas}

Kata "community" menurut Syahyuti berasal dari bahasa latin, yaitu "Cum" yang mengandung arti kebersamaan dan "Munus" yang bermakna memberi antara satu sama lain, sehingga dapat diartikan bahwa komunitas adalah sekelompok orang yang saling berbagi dan mendukung antara satu sama lain. Komunitas dapat dimaknai sebagai sebuah kelompok dari suatu masyarakat atau kelompok orang yang hidup di suatu area khusus yang memiliki karakteristik budaya yang sama. Komunitas memiliki sifat interaksi, di mana interaksi yang ditekankan lebih kepada interaksi informal dan spontan daripada interaksi formal, serta memiliki orientasi yang jelas. Ciri utama sebuah komunitas adalah adanya keharmonisan, egalitarian, serta sikap saling berbagi nilai dan kehidupan.

\section{Pengembangan Diri}

Pengembangan diri adalah suatu proses pembentukan potensi, bakat, sikap, perilaku dan kepribadian seseorang melalui pembelajaran dan pengalaman yang dilakukan berulang-ulang sehingga meningkatkan kapasitas atau kemampuan diri sampai pada tahap otonomi (kemandirian). 
Berikut ini adalah definisi dan pengertian pengembangan diri dari beberapa sumber buku:

- Menurut Marmawi (2009), pengembangan diri adalah suatu proses meningkatkan kemampuan atau potensi, dan kepribadian, serta sosial-emosional seseorang agar terus tumbuh dan berkembang.

- Menurut Tarmudji (1998), pengembangan diri adalah mengembangkan bakat yang dimiliki, mewujudkan impian-impian, meningkatkan rasa percaya diri, menjadi kuat dalam menghadapi percobaan, dan menjalani hubungan yang baik dengan sesamanya.

- Menurut DEPAG (2005), pengembangan diri adalah proses pembentukan sikap dan perilaku yang relatif menetap melalui pengalaman yang berulang-ulang sampai pada tahap otonomi (kemandirian) mengenai suatu perilaku tertentu.

- Menurut Fanani (2003), pengembangan diri adalah pengembangan segala potensi yang ada pada diri sendiri, dalam usaha meningkatkan potensi berfikir dan berprakarsa serta meningkatkan kapasitas intelektual yang diperoleh dengan jalan melakukan berbagai aktivitas.

\section{METODE}

\section{Deduktif dan Desktiptif Analisis}

Metode riset yang digunakan berupa pendekatan deduktif. Sumbernya berdasarkan pengetahuan sebelumnya yang bersifat umum serta menyimpulkan pengetahuan baru yang bersifat khusus (Mardiyantoro, 2019). Dalam hal ini penelitian menggunakan literatur dan media elektronik dalam mencari dan mengumpulkan data. Data-data yang dikumpulkan dari berbagai sudut pandang masyarakat dikelompokkan untuk mencari satu solusi terbaik dan efektif guna mengatasi masalah perspektif masyarakat terhadap guna narapidana di Indonesia. Selain itu penelitian ini juga berdasarkan atas metode deskriptif analisis. Metode ini berupa paparan yang terjadi saat ini disertai literatur yang mendukung teori yang dihadapi. Dengan penggunaan metode deskriptif, penelitian ini banyak membahas teknik-teknik pengumpulan, pengolahan atau analisis dan penyajian terhadap data-data. Proses analisis data dilakukan secara kualitatif berdasarkan logika dan argumentasi yang bersifat ilmiah. Langkah-langkah ini berupa studi kepustakaan, survey terhadap objek yang menjadi pembanding, serta lokasi dan studi tapak untuk mendapatkan data-data yang berhubungan dengan objek perancangan.

\section{Metode Desain Diagramatis}

Dalam proses penyusunan program, digunakan metode desain diagramatis untuk mempermudah dalam merumuskan program-program detail, kegiatan-kegiatan, pengguna program, dan waktu penggunaan berdasarkan program-program detail tersebut. Metode ini digunakan untuk menstrukturkan bentuk dan konsep arsitektur yang dirancang. Bahasa diagram menjadi penting untuk mendeskripsikan ide sebagai suatu tindakan mencipta (Agustinus, 2020: 100). Skema grafik yang interaktif digunakan untuk membuka peluang dalam mengolah kompleksitas serta kemungkinan lain mengembangkan desain secara abstrak. Data-data yang diperoleh dari studi kepustakaan tentang berbagai preseden yang menunjang, tentang keadaan tapak dan sekitarnya, serta tentang kondisi Lembaga Pemasyarakatan di Indonesia secara umum dirumuskan dalam sebuah informasi berupa grafik dan diagram yang menunjang proses perencanaan konsep yang sesuai dan efektif untuk mengatasi permasalahan yang ada.

\section{DISKUSI DAN HASIL}

\section{Pemilihan Lokasi}

Lokasi proyek berada di Desa Ciangir, Kecamatan Legok, Kabupaten Tangerang yang berbatasan dengan Kecamatan Curug di sebelah utara, Kabupaten Bogor di sebelah Selatan, Kecamatan Panongan di sebelah barat, dan Kecamatan Pagedangan di sebelah timur. Menurut data BPS, terjadi peningkatan angka kemiskinan yang terjadi di Kabupaten Tangerang setiap tahunnya, yang tentu dapat 
berimplikasi pada peningkatan kasus kriminalitas di kawasan tersebut. Penduduk di Kecamatan Legok didominasi usia bayi, anak-anak, dan remaja. Hal ini tentu dapat membuka peluang untuk memberikan ruang belajar bagi muda-mudi untuk membuka diri lebih luas sejak dini dalam menanggapi positif stigma sosial dan persepsi negatif masyarakat terhadap status narapidana di Indonesia yang terus berkembang.
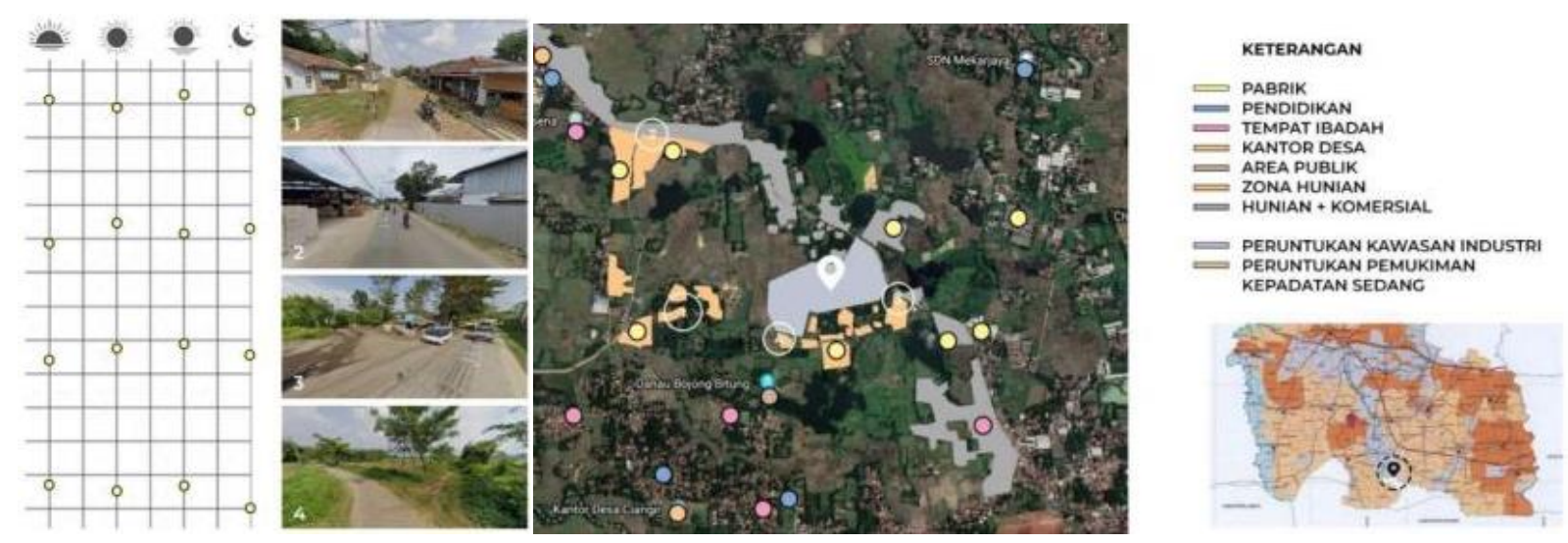

Gambar 1. Lokasi Kecamatan Legok, Kabupaten Tangerang

Sumber: Penulis, 2021

\section{Tapak}

Pemilihan tapak dengan kriteria yang sesuai dengan konsep LAPAS baru yang ingin ditonjolkan, yaitu berada di area yang didominasi pertanian dan pemukiman penduduk untuk menunjang integrasi positif antara warga binaan pemasyarakatan dengan masyarakat. Pertanian dan perkebunan dapat menjadi kegiatan utama di dalam LAPAS untuk fungsi rehabilitasi, penyembuhan, dan kontemplasi diri. Tapak tersebut berada di Jalan Raya Rancaiyuh, Kecamatan Legok, Kabupaten Tangerang. Tapak berada di jalan kolektor sekunder dan jalan lokal. Pemilihan tapak di jalan raya utama dikarenakan intensitas kendaraan dan aktivitas manusia yang lebih tinggi dengan akses jalan yang memadai sehingga mendukung program integrasi WBP dalam masyarakat. Tapak ini juga berada dalam jarak sekitar 2,5 km dengan LAPAS terbuka Ciangir yang merupakan LAPAS dengan tingkat keamanan medium, sehingga berpotensi membentuk koneksi antara LAPAS terbuka tersebut dengan konsep LAPAS yang diajukan dengan tingkat keamanan maksimum dan minimum.

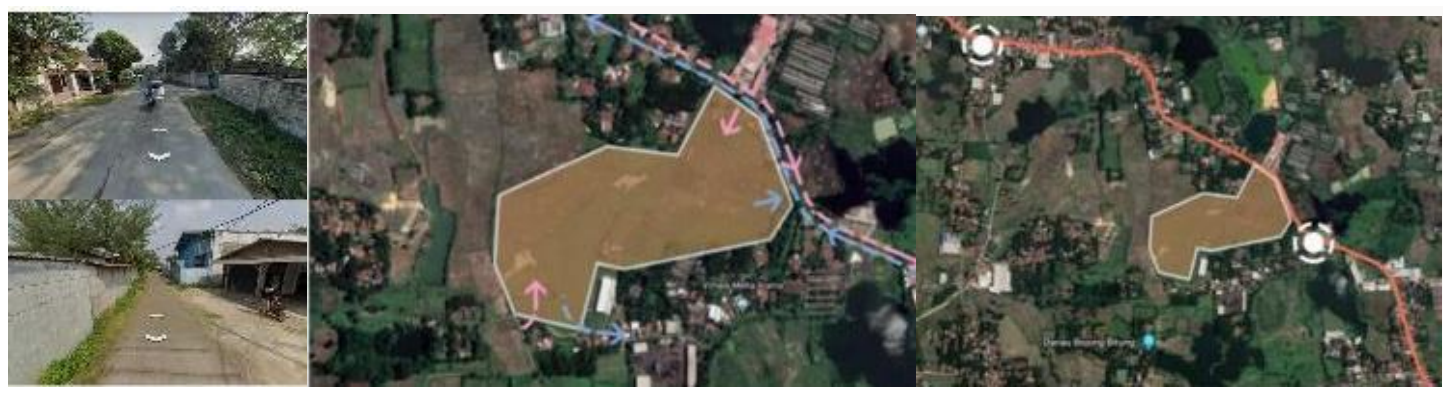

Gambar 2. Lokasi Kecamatan Legok, Kabupaten Tangerang Sumber: Penulis, 2021 


\begin{tabular}{|c|c|c|c|}
\hline STRENGTH & WEAKNESS & OPPORTUNITY & THREAT \\
\hline $\begin{array}{l}\text { Berada di lokasi dengan } \\
\text { kepadatan lalu lintas } \\
\text { rendah } \\
\text { Pembentukan } \\
\text { komunitas baru yang } \\
\text { lebih akrab dengan } \\
\text { masyarakat di } \\
\text { lingkungan pemukiman } \\
\text { Membentuk koneksi } \\
\text { dengan Lapas Kelas IIB } \\
\text { Terbuka Ciangir }\end{array}$ & $\begin{array}{l}\text { Jalan sekitar } \\
\text { tapak tidak ramah } \\
\text { pejalan kaki } \\
\text { Pencahayaan } \\
\text { buatan tidak } \\
\text { berfungsi } \\
\text { maksimal }\end{array}$ & $\begin{array}{l}\text { Peluang menjalin relasi } \\
\text { yang lebih baik antara } \\
\text { warga } \\
\text { binaan dengan } \\
\text { masyarakat umum } \\
\text { maupun warga setempat } \\
\text { (ekonomi, sosial, budaya) } \\
\text { Potensi pengembangan } \\
\text { kawasan pertanian di } \\
\text { area tapakdan sekitarnya }\end{array}$ & $\begin{array}{l}\text { Perasaan takut yang } \\
\text { mungkin muncul dari } \\
\text { pejalan kaki } \\
\text { pada malam hari } \\
\text { Fungsi jalur pedestrian } \\
\text { yang tidak optimal } \\
\text { berpotensi } \\
\text { menyebabkan } \\
\text { kecelakaan (jalur fungsi } \\
\text { ganda untuk pedestrian } \\
\text { dan kendaraan) }\end{array}$ \\
\hline
\end{tabular}

Tabel 1. Tabel SWOT Tapak di Desa Ciangir, Kecamatan Legok

Sumber: Penulis, 2021

\section{Konsep}

Proyek rumah pemasyarakatan untuk warga binaan ini mengangkat konsep community and self development. Penciptaan ruang-ruang terbuka dengan memasukkan unsur alam yang eksisting di area tapak diharapkan dapat menjadi fasilitas rehabilitasi pribadi maupun sosial bagi WBP, serta media kontemplasi diri dengan alam sebagai elemen utama. Pembentukan ruang terbuka juga dimaksudkan untuk memberikan kesan "mengundang" bagi masyarakat umum yang memang diperlukan untuk membantu penyembuhan diri WBP melalui interaksi sosial langsung dengan masyarakat. Pembentukan ruang-ruang komunitas yang sehat bagi warga binaan untuk sekedar berkumpul, berdiskusi, atau merenungkan diri ditonjolkan dengan harmonisasi langsung dengan alam yang masih dominan. Selain itu, peternakan juga menjadi elemen penting yang mendukung fungsi rumah pemasyarakatan sebagai salah satu media kontemplasi diri dan aktivitas penunjang kegiatan di dalam LAPAS. Peternakan juga berperan dalam mendukung fungsi pertanian dan perkebunan yang menyatu dengan pemukiman di sekitar tapak, serta irigasi untuk persawahan yang berpusat pada kolam ternak ikan di mana kolam itu bisa digunakan untuk meningkatkan nilai ekonomi masyarakat setempat. Pemanfaatan air kotor yang difiltrasi dan dimanfaatkan untuk fungsi pertanian yang dominan di area tapak dan sekitarnya menjadi konsep yang juga menunjang tema prison ecology yang diangkat dalam desain LAPAS. Implementasi konsep ini memberikan ruang gerak fleksibel bagi warga binaan untuk bisa berekspresi sesuai dengan minat, kewajiban, dan pekerjaannya. Segala aspek yang bersinergi dengan alam dan lingkungan secara tidak langsung menyatukan kembali mereka melalui partisipasi dan kontribusi positif di tengah masyarakat terutama di bidang pertanian, peternakan, dan teknologi yang juga berperan besar dalam kehidupan masyarakat sehari-hari. 

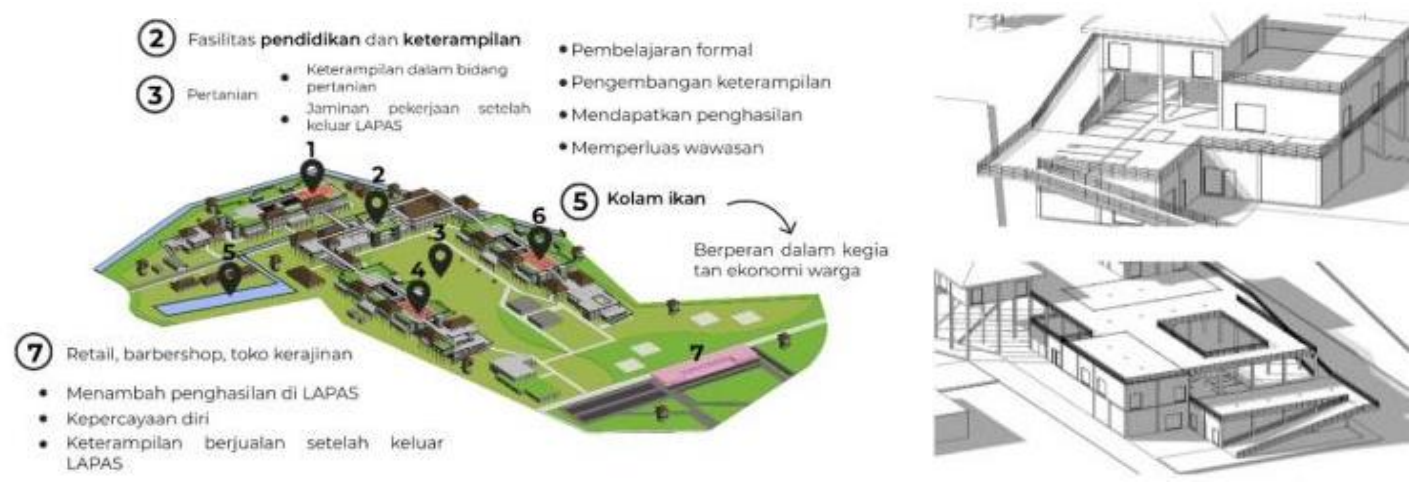

Gambar 3. Keterangan Fungsi pada Tapak dan Massa Bangunan

Sumber: Penulis, 2021

\section{Proses Gubahan}

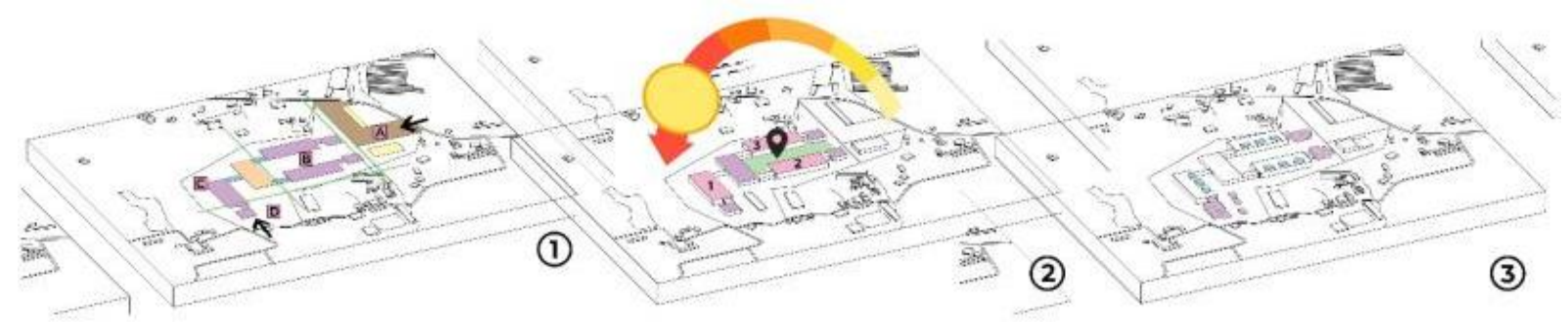

Gambar 4. Proses Gubahan Massa

Sumber: Penulis, 2021

Proses pertama dengan membagi area tapak menjadi area publik yang terletak di titik $A$ dan $D$, area semi publik di titik $B$ untuk fungsi hunian, kantor, dan pertanian, serta area privat di titik $C$ untuk fungsi hunian maximum security kejahatan narkotika dan pusat pendidikan. Jalan masuk alternatif di area $D$ berfungsi sebagai area masuk-keluar narapidana minimum security, sedangkan area A sebagai akses masuk utama ke dalam Lembaga Pemasyarakatan. Proses berikutnya dengan membuat massa yang dinamis dengan ketinggian bangunan yang berbeda menyesuaikan fungsi untuk sekaligus mengatur pencahayaan agar dapat dimanfaatkan untuk fungsi-fungsi sesuai seperti pertanian, olahraga, kamar tidur yang nyaman, serta area publik untuk fungsi rehabilitasi. Sentralisasi yang terpusat pada area pertanian sebagai pusat kegiatan utama. Eksisting sawah dan perkebunan dipertahankan untuk menjaga ekosistem habitat alami. Fleksibilitas hunian diterapkan dengan konsep rumah tinggal pada minimum security yang tersebar di area tapak, mulai dari lantai dasar hingga lantai teratas. Tapak dengan lingkungan sekitarnya dibatasi secara soft/halus dengan vegetasi yang juga berperan sebagai perkebunan untuk menunjang kebutuhan warga binaan, masyarakat, dan kebutuhan alam di sekitar tapak yang berada di zona industri dan pemukiman. 


\begin{tabular}{|c|c|c|c|c|c|}
\hline $\begin{array}{l}\text { ENERGY+ } \\
\text { EMISSION }\end{array}$ & $T$ & $N$ & $E$ & $H$ & $\begin{array}{l}\text { SUSTAINABLE } \\
\text { DIGITAL }\end{array}$ \\
\hline $\begin{array}{l}\text { Dominasi } \\
\text { material bata } \\
\text { yang ramah } \\
\text { lingkungan } \\
\text { dengan beton } \\
\text { ditunjang oleh } \\
\text { konsep } \\
\text { penghijauan di } \\
\text { area rooftop } \\
\text { dan pertanian } \\
\text { serta } \\
\text { perkebunan } \\
\text { yang luas di } \\
\text { area tapak. }\end{array}$ & $\begin{array}{l}\text { Interaksi } \\
\text { aktivitas } \\
\text { bangunan } \\
\text { dengan } \\
\text { elemen alam } \\
\text { di sekitarnya. } \\
\text { Pengudaraan } \\
\text { dan } \\
\text { pencahayaan } \\
\text { alami sebagai } \\
\text { penunjang } \\
\text { utama konsep } \\
\text { bangunan. }\end{array}$ & $\begin{array}{l}\text { Pertanian, } \\
\text { perkebunan, } \\
\text { sawah yang } \\
\text { dominan } \\
\text { untuk resapan } \\
\text { air yang juga } \\
\text { didukung oleh } \\
\text { irigas dan } \\
\text { kolam ternak } \\
\text { ikan yang } \\
\text { dapat saling } \\
\text { menunjang. }\end{array}$ & $\begin{array}{l}\text { Pemanfaata } \\
\mathrm{n} \text { solar panel } \\
\text { yang } \\
\text { dikombinasi } \\
\text { kan dengan } \\
\text { PLN untuk } \\
\text { pemulihan } \\
\text { kembali } \\
\text { gangguan } \\
\text { listrik, serta } \\
\text { pengelolaan } \\
\text { listrik yang } \\
\text { mandiri dan } \\
\text { ramah } \\
\text { lingkungan. }\end{array}$ & $\begin{array}{l}\text { Penggunaan } \\
\text { teknologi } \\
\text { terbarukan } \\
\text { dalam } \\
\text { konsep } \\
\text { LAPAS, } \\
\text { seperti } \\
\text { CCTV, sensor } \\
\text { jarak jauh, } \\
\text { metal } \\
\text { detector, } \\
\text { teknologi } \\
\text { sidik jari, dan } \\
\text { lain-lain. }\end{array}$ & $\begin{array}{l}\text { Penciptaan } \\
\text { ruang-ruang } \\
\text { komunitas } \\
\text { yang } \\
\text { berinteraksi } \\
\text { langsung } \\
\text { dengan alam } \\
\text { di sekitarnya } \\
\text { untuk fungsi } \\
\text { rehabilitasi } \\
\text { medis, karya, } \\
\text { dan sosial. }\end{array}$ \\
\hline
\end{tabular}

Tabel 2. Tabel Kesesuaian Desain dengan Parameter Beyond Ecology

Sumber: Penulis, 2021

\section{Kebutuhan Ruang Hunian}

Jumlah hunian maximum security $=288$ unit dengan ketentuan

Massa hunian A terdapat 96 unit kamar; massa B terdapat 96 unit kamar; dan massa C terdapat 96 unit kamar.

Jumlah hunian minimum security tipe $1(4 \mathrm{KT})=30$ unit hunian

Jumlah hunian minimum security tipe $2(2 \mathrm{KT})=3$ unit hunian

Sehingga kapasitas Warga Binaan Pemasyarakatan di dalam LAPAS berjumlah 418 orang (288 penghuni maximum security dan 126 penghuni minimum security)

Luasan ruang/kamar hunian (tidak termasuk luasan kamar mandi dan WC) ditentukan bahwa setiap penghuni harus mendapatkan ruang gerak seluas 5,4 $\mathrm{m} 2$. Standar tersebut merupakan hasil kajian dan riset dari Dr. Silvia Casole pada penjara-penjara di Amerika Serikat dan negara-negara sekitar Atlantik maupun di negara-negara Eropa (Silvia, 1996: 21-23). Hasil kajian dan riset tersebut dapat diterapkan dalam kondisi negara Indonesia dengan pertimbangan sebagai berikut:

Perhitungan kapasitas kamar hunian menurut standar tersebut adalah :

Kapasitas kamar hunian $=\mathrm{X}($ Luasan Kamar Hunian $) / 5,4$

Ruang hunian untuk 1 orang berukuran +-12 meter persegi + WC/kamar mandi
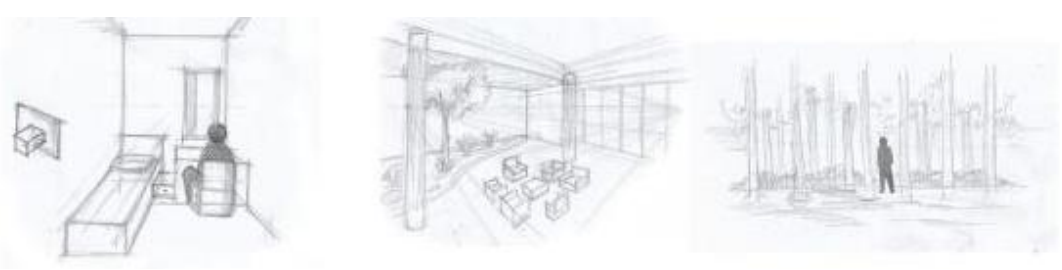

Gambar 5. Sketsa Ruang pada Rumah Pemasyarakatan

Sumber: Penulis, 2021 
Total luas unit hunian dan kelengkapannya di maximum security adalah 5836 meter persegi, sementara luas unit hunian di minimum security adalah 6300 meter persegi sehingga luas total unit hunian keseluruhan adalah 12156 meter persegi. Jumlah ini tentu dapat menjadi jawaban permasalahan kelebihan kapasitas pada sebagian besar Lembaga Pemasyarakatan di Indonesia, yang tidak hanya bermasalah secara kuantitas, namun juga dari segi kualitas. Oleh sebab itu memang diperlukan juga kesinambungan desain dengan program-program yang mendukung penurunan kelebihan kapasitas dan residivisme sehingga kasus-kasus kejahatan bisa diredam dan dikurangi. Desain kamar untuk perorangan dapat menjadi sarana refleksi diri secara pribadi dan khusus untuk keperluan setiap warga binaan, sehingga proses rehabilitasi bisa lebih terarah untuk perbaikan dan perubahan mental, pola pikir, serta emosional warga binaan sendiri.

\section{Programming}

Pembentukan ruang terbuka yang menghubungkan hunian tipe 1 dan hunian tipe 2. Pemanfaatan ruang terbuka sebagai sarana rehabilitasi warga binaan dengan unsur alam yang dominan sebagai elemen utama dari healing space. Konektor dua tipe hunian dihubungkan oleh fungsi kantor utama untuk mempermudah pengawasan dan kontrol serta pusat pendidikan dan keterampilan untuk menunjang kegiatan warga binaan pemasyarakatan secara pribadi maupun sosial dengan masyarakat yang datang/berkunjung.

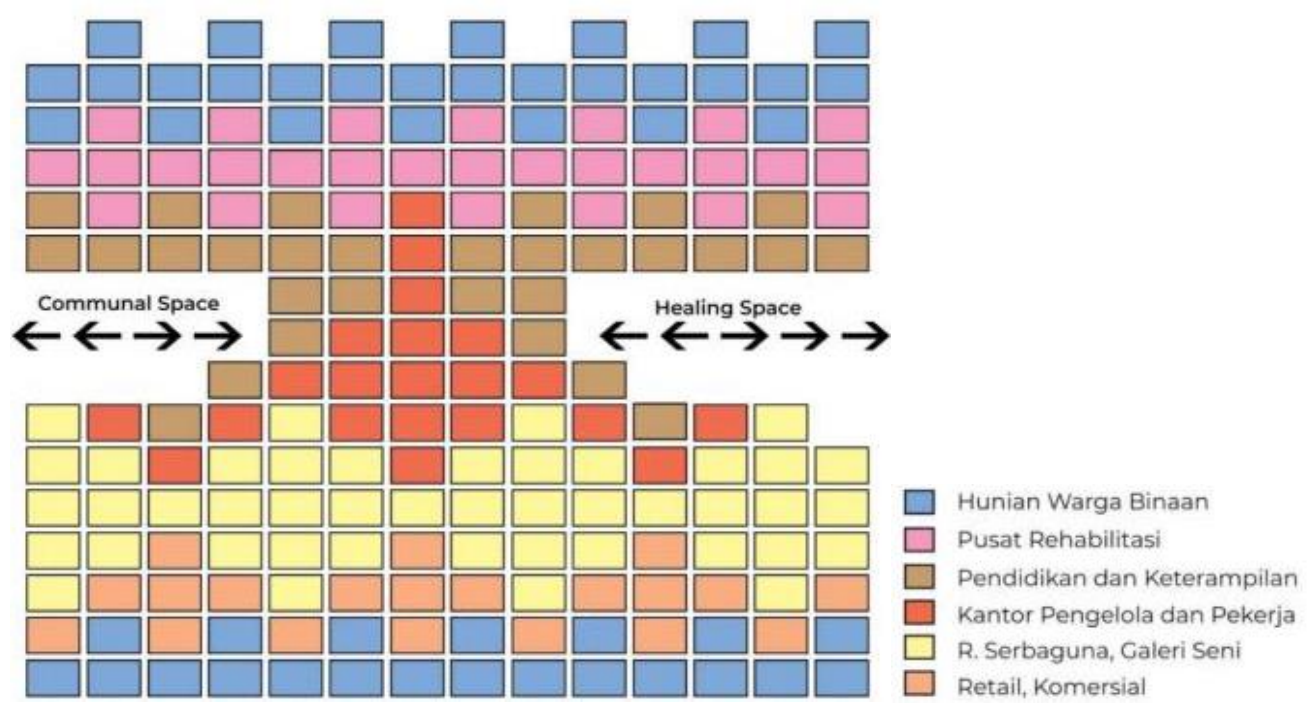

Gambar 6. Diagram Zoning Vertikal Sumber: Penulis, 2021

Zoning horizontal membagi area utama untuk kepentingan publik di area depan seperti retail, area publik, taman, pos pengamanan. Kantor utama menjadi penghubung area luar dengan zona hunian. Area publik untuk para penghuni berada di tengah yang juga berfungsi sebagai pusat kegiatan utama narapidana yaitu pertanian dan perkebunan. Pembentukan area publik di tengah fungsi bangunan menunjukkan vitalnya peran ruang terbuka untuk membentuk komunitas dalam desain Lembaga Pemasyarakatan ini. 


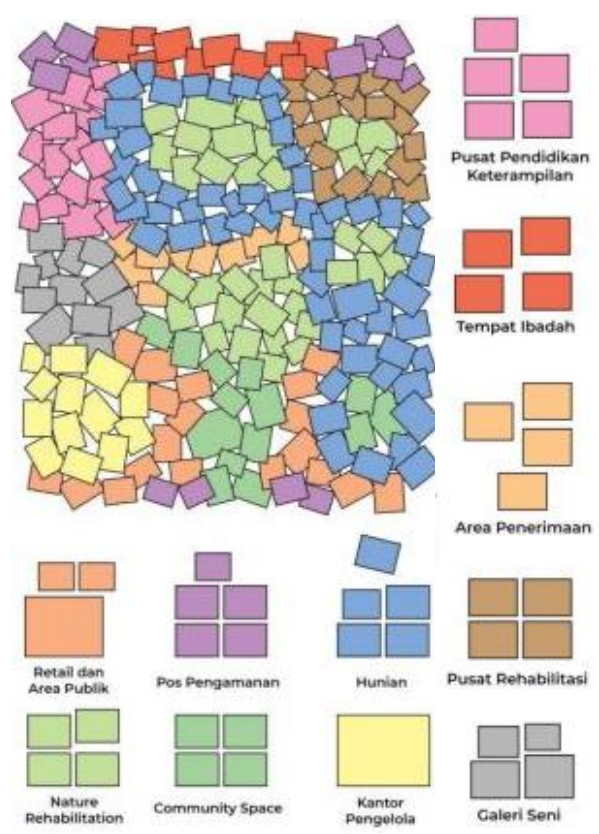

Gambar 7. Diagram Zoning Horizontal Sumber: Penulis, 2021

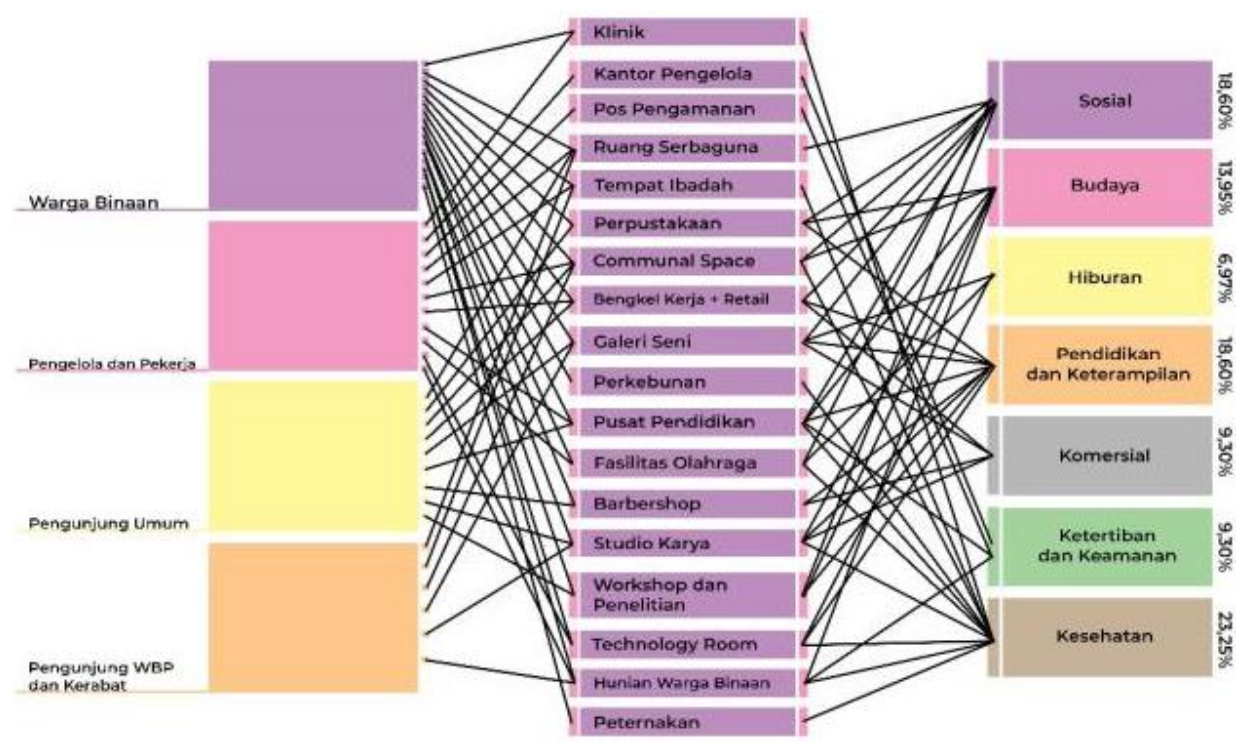

Gambar 8. Diagram Programming Sumber: Penulis, 2021

\section{Sistem Keamanan}

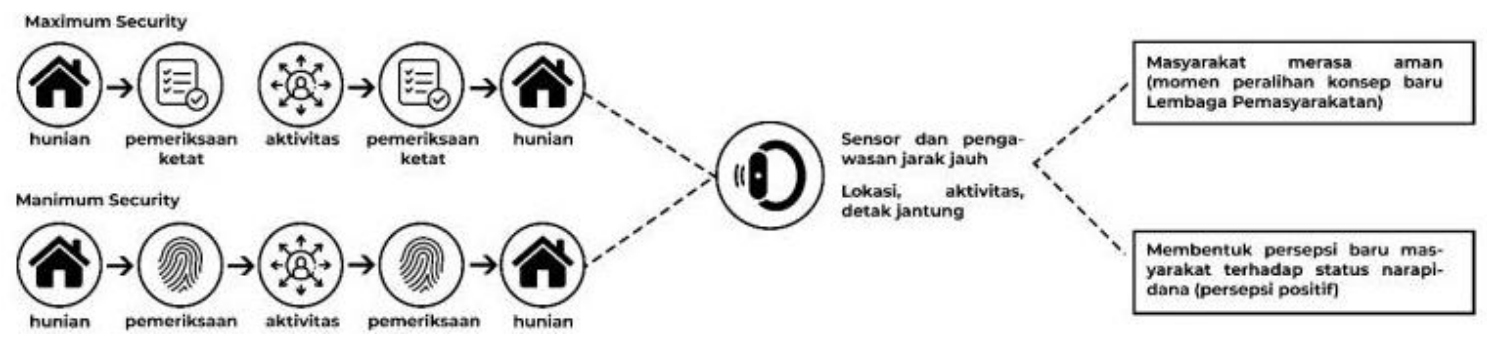


Area hijau berupa perkebunan di sepanjang sisi tapak yang menyatu dengan perkebunan asli di area pemukiman. Pemisahan area maximum security dengan lingkungan sekitar melalui vegetasi yang menyatu dengan perkebunan warga dan kolam ikan yang juga berfungsi untuk irigasi. Pemisahan area maximum dan minimum security dengan vegetasi sebagai area publik dan pagar dengan tinggi sekitar $90 \mathrm{~cm}$. Berbagai jenis pohon dan tanaman yang ditata secara dinamis dan memusat.
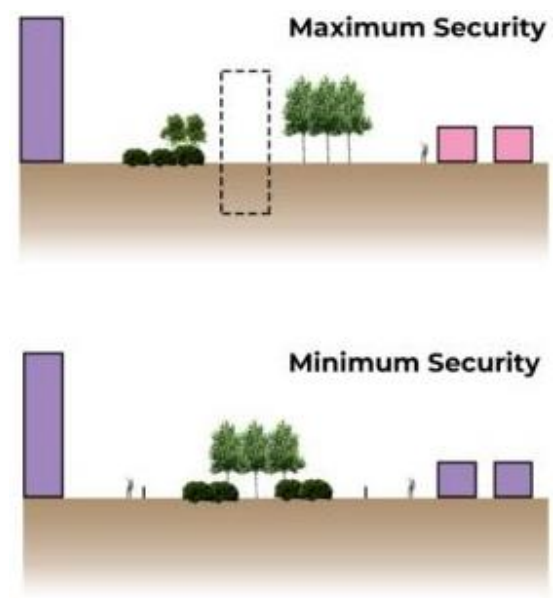

Gambar 9. Batasan pada Hunian Sumber: Penulis, 2021
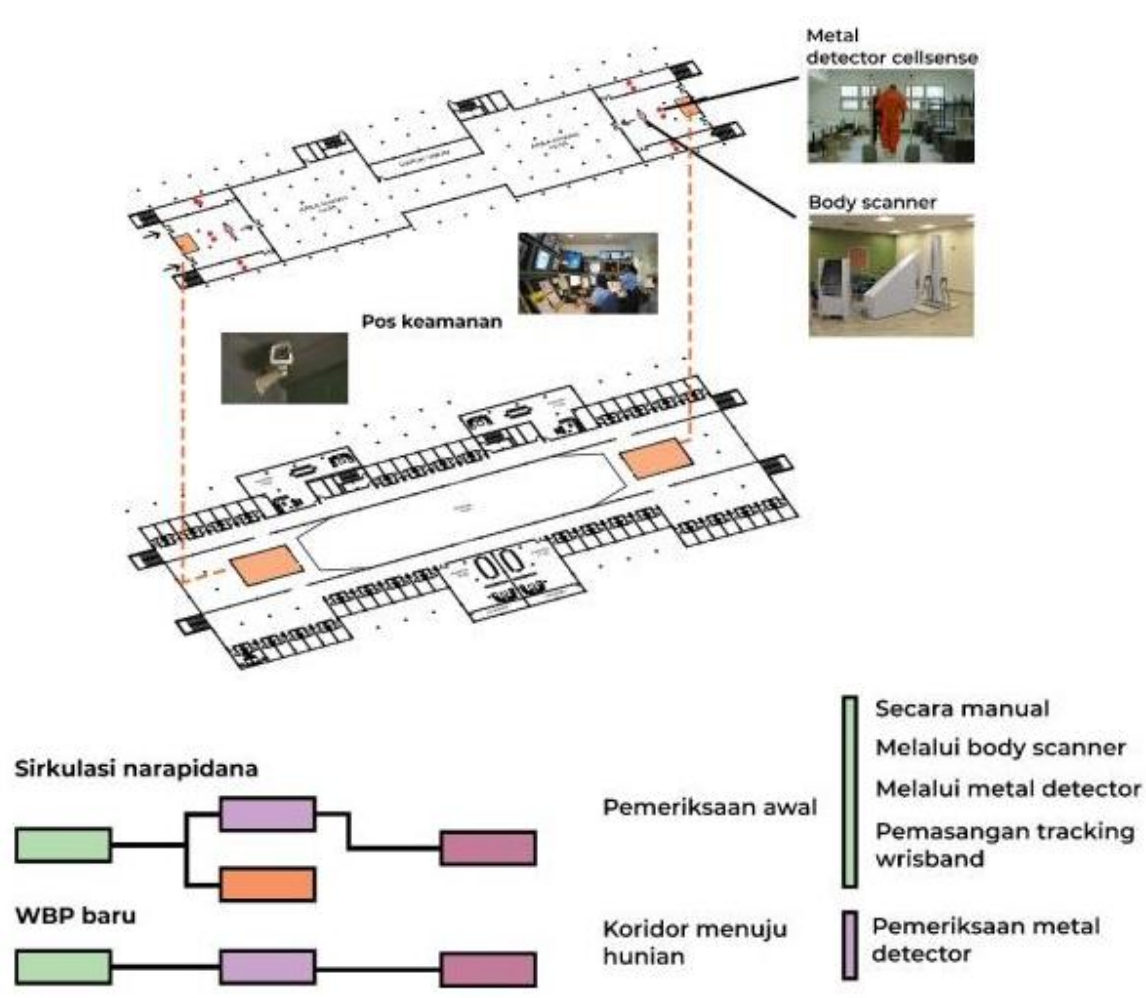

Gambar 10. Sistem Keamanan Rumah Pemasyarakatan Sumber: Penulis, 2021 


\section{Sirkulasi dan Batasan Area Kegiatan}
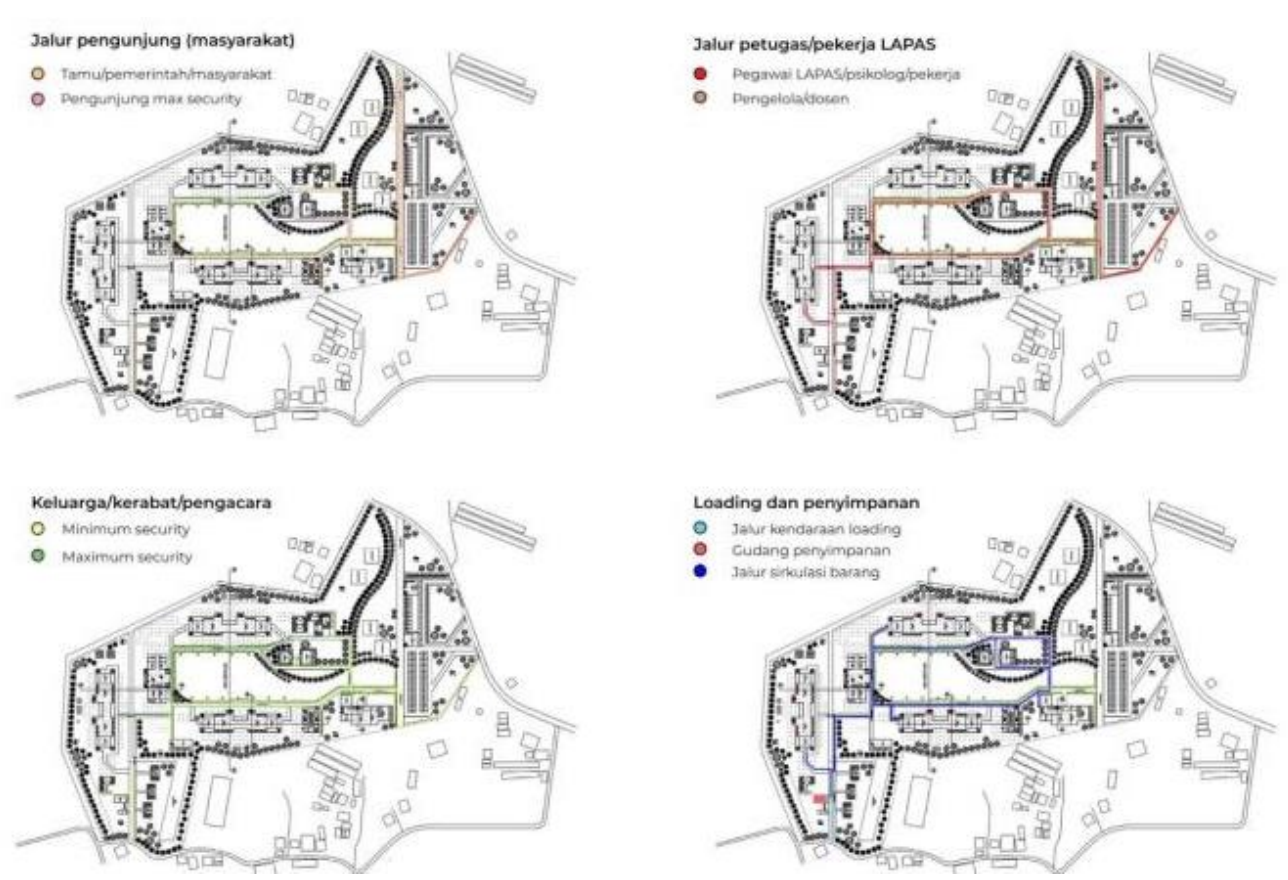

Gambar 11. Jalur Sirkulasi Pengguna di dalam Tapak Sumber: Penulis, 2021

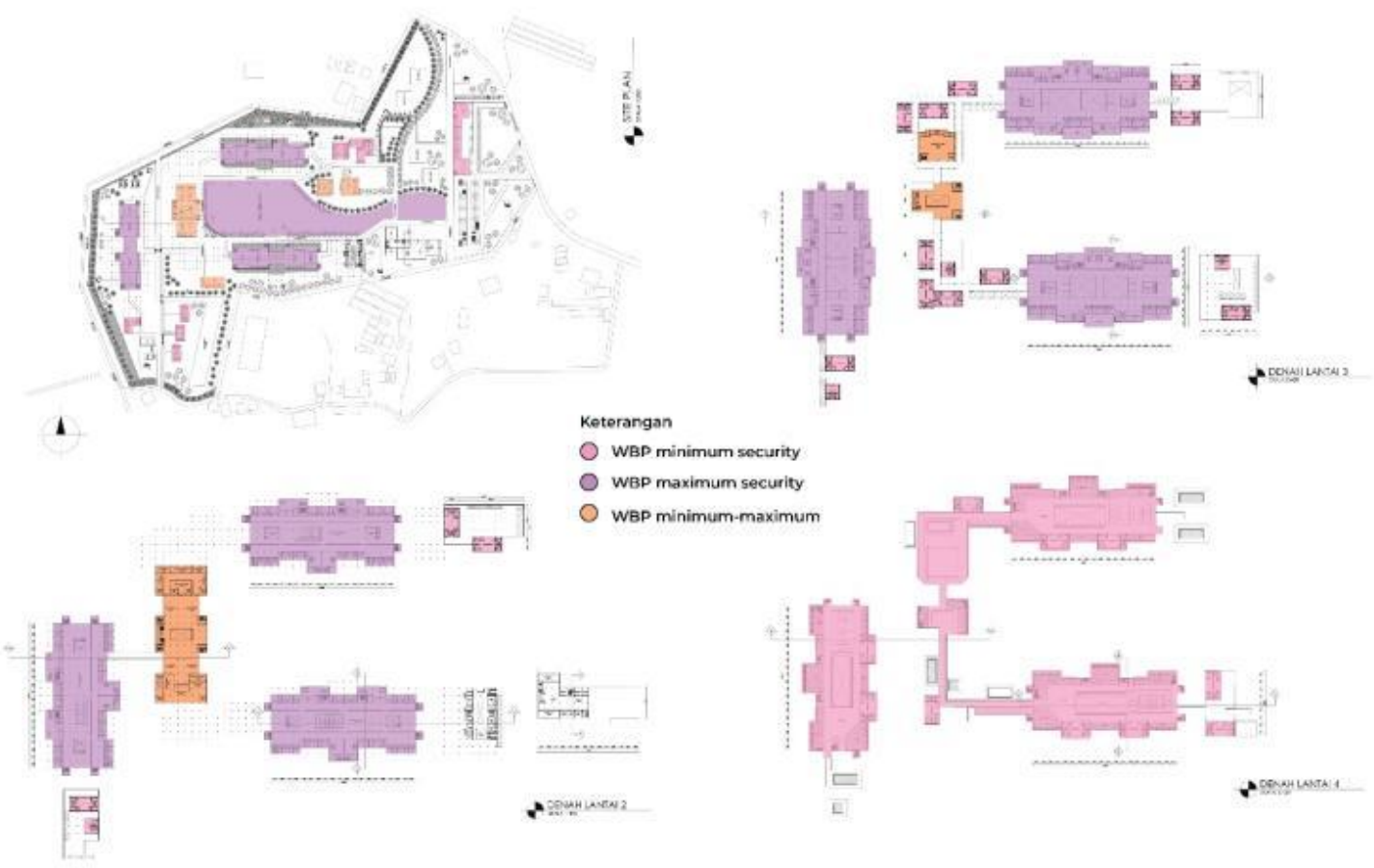

Gambar 12. Batasan Area Kegiatan Warga Binaan Sumber: Penulis, 2021 


\section{KESIMPULAN DAN SARAN}

\section{Kesimpulan}

Berdasarkan isu utama yang diangkat mengenai stigma sosial dan persepsi negatif masyarakat terhadap status narapidana yang terus berkembang, solusi dari hasil dan analisis perancangan yang dihasilkan adalah dengan perencanaan proyek rumah pemasyarakatan dengan fokus utama pengembangan kualitas diri warga binaan. Konsep fleksibilitas diangkat untuk membentuk komunitas sehat bagi warga binaan sehingga proses rehabilitasi dapat berjalan efektif dan efisien guna menekan kasus kelebihan kapasitas di sebagian besar LAPAS di Indonesia. Hal ini juga diupayakan agar efektivitas dan efisiensi program rehabilitasi dapat mengurangi kasus residivisme yang terus mengalami peningkatan dari tahun ke tahun. Konsep rumah pemasyarakatan juga membuka interaksi bagi warga binaan terhadap masyarakat umum sehingga stigma tersebut bisa perlahan lebur dan akhirnya menjadi sesuatu hal yang tidak perlu dikhawatirkan lagi. Pertanian dan perkebunan menjadi elemen alam dominan, yang juga berperan sebagai healing space yang dimanfaatkan dalam konsep rumah pemasyarakatan untuk menciptakan kegiatan-kegiatan positif, sarana kontemplasi dan rehabilitasi bagi warga binaan, maupun masyarakat setempat.

\section{Saran}

Kemungkinan studi atau desain lanjutan dalam proses perancangan adalah keberlanjutan desain untuk mengatasi kelebihan kapasitas dengan mempersiapkan area kolom dan balok ekspos yang dapat dimanfaatkan lebih lanjut untuk kepentingan hunian serta fungsi lain. Area yang sementara dimanfaatkan untuk penghijauan tanaman rambat di sepanjang balok ekspos.

\section{REFERENSI}

Akhyar, Z., Harpani, M., dan Najibuddin, M. (2014). Persepsi Masyarakat terhadap Mantan Narapidana di Desa Benua Jingah Kecamatan Barabai Kabupaten Hulu Sungai Tengah. Jurnal Pendidikan Kewarganegaraan, 4(7), 545-547.

Allen, D. And Abadi, M. (2020). At prisons in Finland, inmates are learning Al and taking online tech courses as a bridge to life on the outside.

Casole, S. (1996). Bidang Pelayanan Kepenjaraan. Departemen Kehakiman.

Hairi, P. J. (2018). Konsep dan Pembaruan Residivisme dalam Hukum Pidana di Indonesia. Pusat Penelitian Badan Keahlian DPR RI, 199-216.

Howison et al. (1990). Psychology in Prisons. London: Routledge

Sutanto, A. (2020). Peta Metode Desain. Jakarta: Universitas Tarumanagara.

Turner, J. (2016). The Prison Boundary : Between Society and Carceral Space. Leicester: Palgrave Macmillan. 
